\title{
AN EX-ANTE ASSESSMENT OF CITY DISTRIBUTION ALTERNATIVES BASED ON MULTI ACTOR MULTI CRITERIA FRAMEWORK ${ }^{1}$
}

\author{
Türkan Müge ÖZBEKLER 2 \\ Arzu KARAMAN AKGÜL ${ }^{3}$
}

\author{
Received Date (Başvuru Tarihi): \\ Accepted Date (Kabul Tarihi): \\ Published Date (Yayın Tarihi):
}

$16 / 10 / 2020$

$9 / 12 / 2020$

$25 / 12 / 2020$

In the article, the first author is in the role of the Corresponding Author.

\section{ABSTRACT}

Keywords:

City Logistics,

Multi Actor Approach,

Multi-Criteria Decision Making,

Consolidation Strategy

JEL Codes:

L90, L91, D70
Recently, urban areas face challenges that result from negative externalities of traditional distribution networks. Especially, city actors increasingly suffer from issues as inefficient load factors in operations, traffic volume on roads, and noise pollution. To overcome these problems, modern city distribution patterns integrated with the consolidation strategy have the potential to provide satisfying solutions. Align with city actors' expectations, alternatives of consolidation-distribution schemes can offer improvements in both economic, social, and environmental issues. In particular, this study aims at an ex-ante evaluation of city distribution alternatives on the typology of consolidation-distribution schemes ensuring win-win solutions to each city actor. This paper adopts Multi Actor MultiCriteria Analysis (MAMCA) as a novel approach to evaluating different city actors' objectives and a set of city distribution alternatives comprehensively. The paper results highlight that micro consolidation centre facilities can be more suitable in response to city actors' expectations among distribution alternatives to urban consolidation centre and mobile depot. Finally, future research in this topic can focus on evaluating distribution alternatives on a sector basis and marketing types such as B2B and B2C.

\footnotetext{
${ }^{1}$ This study is derived from Türkan Müge Özbekler's doctoral thesis, written in Yıldız Technical University

${ }^{2}$ Lecturer, Sinop University, tozbekler@sinop.edu.tr, $\quad \underline{\text { https://orcid.org/0000-0003-1127-4325 }}$

${ }^{3}$ Assist. Prof. Dr., Yıldız Technical University, akaraman@yildiz.edu.tr, $\quad$ https://orcid.org/0000-0002-4606-6756
} 


\section{ÇOK AKTÖR ÇOK KRITTER ÇERÇEVESINDE KENT DAĞITIM ALTERNATİFLERINIIN ÖN DEĞERLENDİRİLMESİ}

$\ddot{O Z Z}$

Anahtar Kelimeler:

Kentsel Lojistik

Çok Aktörlü Yaklaşım

Çok Kriterli Karar Verme

Konsolidasyon Stratejisi

JEL Kodlarn:

L90, L91, D70
Son zamanlarda kentsel alanlar, geleneksel dağıtım ağlarının olumsuz dışsallıklarından kaynaklanan zorluklarla karşı karşıyadır. Özellikle kent paydaşları, operasyonlardaki verimsiz yük faktörleri, yollardaki trafik hacmi ve gürültü kirliliği gibi sorunlardan giderek daha fazla zarar görmektedir. Bu sorunlarn üstesinden gelmek için, konsolidasyon stratejisiyle entegre olan modern kent dağıtım modelleri tatmin edici çözümler sağlama potansiyeline sahiptir. Kent paydaşlarının beklentileriyle uyumlu olarak, konsolidasyon-dağıtım şema alternatifleri hem ekonomik, sosyal ve çevresel konularda iyileştirmeler sağlayabilir. Bu çalı̧ma özellikle, her kent paydaşına kazan-kazan çözümleri sağlayan konsolidasyon-dağıtım şemalarının tipolojisi üzerinden kent dağıtım alternatiflerinin ön değerlendirilmesini amaçlamaktadır. Çalışma, farkl kent paydaşlarının hedeflerini ve bir dizi kent dağıtım alternatifini kapsamlı bir şekilde değerlendirmek için yeni bir yaklaşım olarak Çoklu Aktör Çoklu Kriter Analizini (MAMCA) benimsemektedir. Çalısma sonuçlarl, mikro konsolidasyon merkezi tesislerinin, kentsel konsolidasyon merkezi ve mobil depo dă̆ıtım alternatifleri arasında kent paydaşlarmın beklentilerine cevap verebilme açısından daha uygun olabileceğini vurgulamaktadır. Son olarak bu konuyla ilgili gelecekteki araştırmalar, dağıtım alternatiflerini sektörel temelde ve B2B ve B2C gibi pazarlama türleri açısından değerlendirmeye odaklanabilir.

\section{INTRODUCTION}

Logistics is a crucial part of our daily lives as long as both production and consumption activities depend on logistics operations to serve society continuously. Turkey's 76\% population lives in urban areas in 2019, and this rate is predicted to become over $86 \%$ in 2050 (DESA, 2019). Along with the concentrated population in cities, headings like the growing consumer base with the booming in e-commerce and personal deliveries, the increase in the number of vehicles in traffic, and the mobility problems created by rapid urbanisation reveal the importance of city logistics. The fact that concerns arising through rapid urbanisation stand out the necessity to reach a better urban freight transport environment regarding mobility, sustainability, and liveability of cities (Malindretos, Mavrommati, \& Bakogianni, 2018). In particular, negative externalities such as traffic congestion, emissions, noise pollution, and visual intrusion constitute priority areas to overcome with suitable logistics solutions as enriching the quality of lives of all city actors.

City logistics, which appear in inner-urban goods transport with the provision of services to provide innovative solutions to customer demands, refers to the last leg of supply chain processes consisting of supply, production, and distribution. City 
logistics can be defined as totally optimising the logistics activities in inner-urban areas while mainly focusing on solving city challenges by developing distribution networks, infrastructure, intermodal platforms, efficient fleet, sustainable transportation modes, so on (Filippi, Nuzzolo, Comi, \& Delle Site, 2010). Savelsbergh \& Van Woensel (2016) suggest that city logistics can create a win-win environment mutually from economic, social, and environmental aspects by adopting consolidation opportunities of freight movement and a better multi-organisation cooperation environment.

In particular, arranging collaborative distribution networks based on consolidation-distribution schemes can facilitate achieving economic gains, such as minimising delivery lead time, improving service levels, and lowering transportation costs (Aljohani \& Thompson, 2018). In parallel with it, decreasing negative externalities on social and environmental issues can be achieved to reach a common benefit through all city stakeholders' expectations from aspects of sustainability, mobility, and liveability (Bektas, Crainic, \& Van Woensel, 2015).

According to Staricco \& Brovarone's (2016) study, city logistics systems can be identified as one or more tiers of consolidation-distribution urban freight schemes. These are urban consolidation centres, micro consolidation centres, and mobile depots based on the type of depot/consolidation platforms from which goods are delivered in city sprawl. In literature, these platforms are generally examined individually according to viability (Allen, Browne, Woodburn, \& Leonardi, 2014), feasibility (Browne, Woodburn, \& Allen, 2007), suitable location (Awasthi, Chauhan, \& Goyal, 2011), delivery fleet (Dablanc, 2007), and sustainability (Björklund, Abrahamsson, \& Johansson, 2017) aspects. Today, while urban consolidation centres are already more common to implement in city logistics concepts, micro consolidation centres, and mobile depots are seen as more innovative solutions even though they are in the exante evaluation stage yet (Janjevic, Kaminsky, \& Ndiaye, 2013; Arvidsson \& Pazirandeh, 2017).

As city logistics is a multi-actor complex phenomenon, expectations through city logistics operations can be diverse among main actors who are mainly categorised as logistics service providers, shippers, receivers, citizens and local authorities 
(Verlinde, Macharis, Milan, \& Kin, 2014). In this regard, the evaluation of potential city logistics strategies and alternatives should be compliant with interdependencies between citizens' welfare, the logistics system, and public administration to facilitate the level of adoption among city actors as creating an inclusive decision process (Aljohani \& Thompson, 2018). Studies related to the multi-stakeholder approach show that the optimal solution may not be sole and depends on each alternative's strengths and weaknesses about each of the stakeholder groups' concerns (Macharis \& Baudry, 2018).

The lack of studies in the literature on the applicability of urban consolidation platforms and related distribution schemes draw attention. Most studies related to city distribution schemes literature are still anecdotal and mainly based on examining single case studies. Studies such as a single consolidation-distribution platform in terms of location (Gonzalez-Feliu, Salanova Grau, \& Beziat, 2014; Simoni, Bujanovic, Boyles, \& Kutanoglu, 2018), company organisation (Allen et al., 2014), cost and benefits (Van Rooijen \& Quak, 2010), economic perspective (Van Duin, Van Dam, Wiegmans, \& Tavasszy, 2016) can be given as examples of this issue. In this study, the main aim is to evaluate all city consolidation-distribution platforms from the perspective of sustainability, namely aspects from economic, social, and environmental, to point out the feasibility of these initiatives to enhance the city's liveability for all city actors. In parallel, cost-benefit analysis on sustainability was performed, and all city consolidation platforms were evaluated comparatively.

Moreover, this study focuses on the actors of city logistics as critical decision makers regarding logistics processes. Remarkably, most of the studies in the literature have examined the distribution system only from the perspective of the industry players. On the contrary to this approach, many stakeholders have different expectations in the urban distribution framework who have an influencing or dramatic role regarding any decision. While economic concerns related to city logistics operations may dominate the logistics service providers, receivers, and shippers, environmental and social concerns also impact all stakeholders' support in the decisions to be taken regarding urban distribution. In this respect, this study evaluates 
the distribution schemes proposed in terms of compliance with the city stakeholders' expectations.

This study presents a novel approach that evaluates the city stakeholders' expectations and the sustainability benefits/costs of city consolidation platforms in a holistic approach. In particular, this study aims at an ex-ante evaluation of city distribution alternatives on the typology of consolidation-distribution schemes from multi-actor perspectives based on ensuring win-win solutions to each city actors in the city logistics framework. This paper adopts Multi Actor Multi-Criteria Analysis (MAMCA) as an extension of the widely used multi-criteria decision-making techniques to evaluate different city actors' objectives and a set of city distribution alternatives in a comprehensive manner. The main research questions of study refer to;

- What are the costs and benefits of different city consolidation-distribution alternatives from the sustainability aspect?

- What are the expectations of different stakeholders in city logistics?

- Which one of the city consolidation-distribution alternatives can be most compliant with stakeholders' expectations?

This study comprises of three main parts. In the first part, the literature review section will be presented briefly, including city logistics and typology of city distribution schemes. In the second part, the methodological path of the study will be explained. Following the MAMCA framework, the study's analysis and conclusions will be put forth in the last part.

\section{LITERATURE REVIEW}

\subsection{City Logistics}

City logistics can be defined as "the process for totally optimising the logistics activities by private companies with the support of advanced information systems in urban areas considering the traffic environment, congestion, safety and the energy savings within the framework of a market economy." (Taniguchi, 2001). The distinguishing characteristic of city logistics can be detailed as the city logistics 
system's effectiveness is based on its ability to manage fluent operations in the innerurban area while taking into account mobility, sustainability, and cities' liveability. From this perspective, city logistics should be compliant with the city environment's dynamism, including city actors, freight operations, logistics networks, and innovative solutions.

Table 1. Main Topics in City Logistics Literature

\begin{tabular}{|c|c|}
\hline Topic & Headings \\
\hline Network Design & $\begin{array}{l}\text { - Facility location } \\
\text { - Integrated distribution networks (one tier or multi tiers) } \\
\text { - Loading/unloading areas } \\
\text { - Pick-up points } \\
\text { - City distribution platforms (Urban consolidation centre, Micro } \\
\text { consolidation centre, mobile depot) }\end{array}$ \\
\hline $\begin{array}{l}\text { Delivery } \\
\text { Strategies }\end{array}$ & $\begin{array}{ll}\text { - } & \text { Night Logistics } \\
\text { - } & \text { Off-hour deliveries } \\
\text { - } & \text { Joint delivery } \\
\text { - } & \text { Load pooling } \\
\text { - } & \text { Tram for goods } \\
\text { - } & \text { Cargo bikes } \\
\text { - } & \text { Electric vehicles } \\
\text { - } & \text { Drones } \\
\end{array}$ \\
\hline $\begin{array}{c}\text { Vehicles } \\
\text { Routing } \\
\text { Problems }\end{array}$ & $\begin{array}{l}\text { - Dynamic re-routing } \\
\text { - } \quad \text { Route optimisation } \\
\end{array}$ \\
\hline $\begin{array}{l}\text { City Policy } \\
\text { Evaluation }\end{array}$ & $\begin{array}{l}\text { - } \quad \text { Congestion charging } \\
\text { - } \quad \text { Road pricing } \\
\text { - } \text { Double-parking enforcement } \\
\text { - } \quad \text { A limited traffic zone } \\
\text { - } \quad \text { Multi-use lanes } \\
\text { - } \quad \text { Low emission zones } \\
\text { - } \quad \text { Logistics zones } \\
\text { - } \quad \text { Public-private partnerships } \\
\text { - Stakeholder involvement } \\
\text { - } \quad \text { Real-time traffic lights }\end{array}$ \\
\hline
\end{tabular}


The main topics from different frameworks handled in city logistics literature can be seen in Table I. In particular, city logistics include complex procedures such as designing infrastructure and service layouts as network design in the strategic decision, routing vehicles for daily deliveries in the operational decision, and figuring out how to best move freight using these network design and routing vehicles in the tactical decision (Bektas et al., 2015). As this study employs a strategic point of view to evaluate city distribution platforms in network design, the critical issue can be defined as designing the flow of goods depending on freight nodes with delivery strategies regarding rising demand from inner-urban areas.

The studies on city network design generally focus on suggesting innovative solutions to improve conventional urban freight network from aspects of reducing both of environmental externalities (e.g., emission, congestions, and noise) and operational costs (e.g., load factor utilisation, convenient facility location) (He, 2020). At this point, Benjelloun \& Crainic (2008) declare that the consolidation strategy based on the bundling of loads of different shippers and carriers within the same city distribution platform can lead to the coordination of operations as reducing vehicle movements and related environmental externalities. The integration of innovative delivery strategies such as joint delivery and utilising green vehicles can also be achieved in line with employing this consolidation-distribution network to manage fluent operations in the inner-urban area while taking into account mobility, sustainability, and liveability of cities (Taniguchi, Thompson, \& Yamada, 2016).

The logic of designing a consolidated distribution network underlines employing city platforms called Urban Consolidation Centers (UCC), Micro Consolidation Centers (MCC), and Mobile Depots (Staricco \& Brovarone, 2016; Lagorio, Pinto, \& Golini, 2016; Simoni et al., 2018). While UCC highlights utilising load factor in goods distribution and often located in the boundaries of the urban zone, MCC points out smaller facilities based on the same logic of UCC but located in the inner-urban area near to population density. Both facilities are employed with aiming to reduce operational costs and utilising to consolidate and coordinate deliveries into smaller and sustainable vehicles such as minivans, electric vans, and cargo bikes (Crainic, Ricciardi, \& Storchi, 2004). Also, mobile depots are a relatively new 
distribution alternative that offers a trailer fitted with a loading dock as a depot supporting cargo bikes (Verlinde et al., 2014).

Lagorio et al. (2016) emphasise in their study that city logistics literature suffers from a lack of studies involving stakeholders in the decision process to improve the technical aspects of the existing solutions or propose new solutions. As city logistics consists of different stakeholders with diverse urban freight transport objectives, coordination is necessary to reach more sustainable and liveable cities. The other point highlighted in that study, there is a need for more attention for the ex-ante evaluation to suggest new solutions or alternatives for taking into account the perspectives of the different city actors. Notably, the cities' morphology and demography can be a significant criterion to affect the proposed solution's efficiency, and ex-ante assessments can identify the feasibility cut point in alignment with city actors' expectations (Faure, Burlat, \& Marquès, 2016).

\subsection{Typology of City Distribution Schemes}

Studies that proposed a systematic approach to city logistics distribution patterns highlight the importance of consolidation-distribution platforms depending on how deliveries can be conducted from the facility to the inner-urban area in the spatial structure scope (Ducret \& Delaître, 2013; Bektaş et al., 2015; He, 2020). The study by Staricco \& Brovarone (2016) employs a three-level classification based on the typology of city consolidation-distribution schemes, which are defined as urban consolidation centres, micro consolidation centres, and mobile depots. This typology is mostly employed in related studies as it reflects initiatives to improve conventional urban freight system from the consolidation framework (Björklund \& Johansson, 2018; Winkenbach \& Janjevic, 2018). In this regard, this study adopts the identification of characteristics of consolidation-distribution schemes based on typology proposed by Staricco \& Brovarone (2016) for the city logistics distribution system.

Conventional distribution relies on the logic of delivering goods from point $\mathrm{A}$ to point $\mathrm{B}$ directly. It means distributing goods from factories and warehouses to innerurban areas without using any transhipment facility and generally via heavy commercial vehicles, which can also face half truckload on delivery (Browne et al., 
2007). This distribution pattern can provide benefits, mainly from an economic perspective regarding attributes of goods type (bulk delivery), customer type (commercial), or place type (close-range delivery). Particularly in B2B marketing, maximising vehicle loads can be possible to manage as the delivery volume is high, and the delivery point is stable. Nevertheless, there are lots of suppliers and customers in the market area, reaching the load factor to overcome operational costs of delivery create pressure on conventional distribution. Also, this distribution scheme can cause ineffective operations regarding parcel deliveries, which are required to distribute to multi located end consumers as the last mile delivery because of a lack of utilisation of resources efficiently and constraint on mobility through the inner-urban area (Taniguchi et al., 2016).
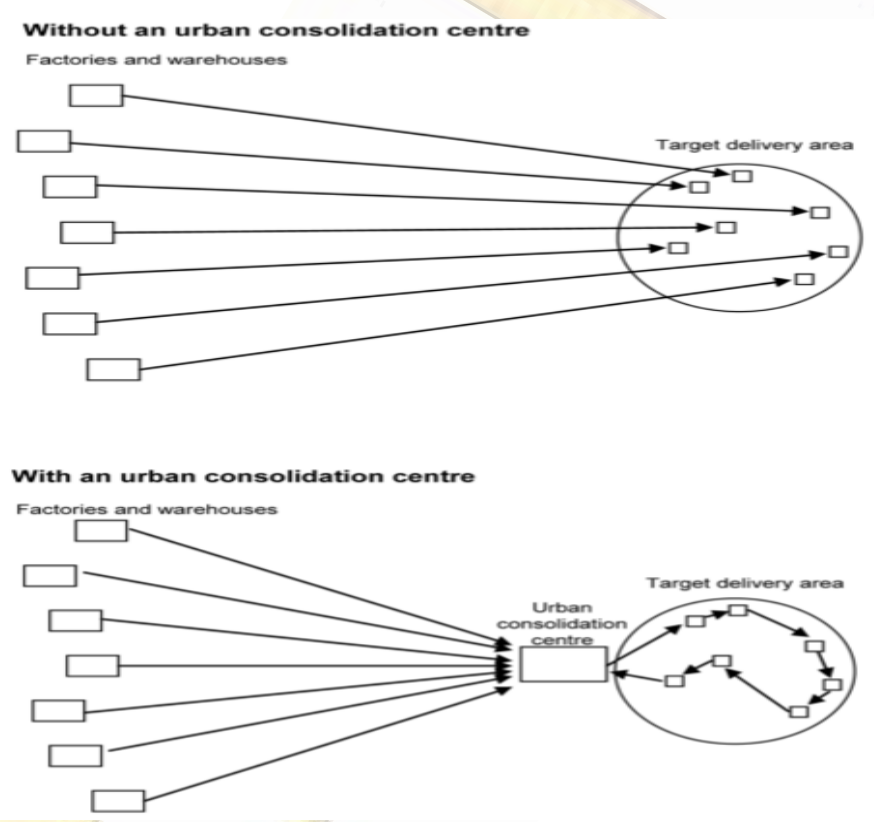

Figure 1. Conventional Distribution versus Distribution via UCC

Source: Adopted from Allen et al. (2014)

Due to the main characteristics of conventional distribution scheme, which lead to negative impacts on the city regarding sustainability, urban freight logistics is responsible for about $20 \%$ of $\mathrm{CO} 2$ emissions born of heavy commercial vehicles and traffic congestion resulting from the high delivery frequency trips (Daggers, 2013). Leading solutions to improve the city distribution system on behalf of society's mutual benefits can be pointed as focusing on cooperation in delivery and replacing larger trucks with smaller ones. As seen in Figure 1, conventional distribution leads to 
dispersed operations without taking into account any considerations regarding sustainability, whereas distribution via urban consolidation centres (UCC) provides systematic patterns based on cycle regarding consolidation and cooperation strategies.

UCC refer to giant transhipment points located in the city centre's proximity as aiming to prevent delivering part loads by heavy commercial vehicles to inner-urban areas (Browne et al., 2007). In this distribution scheme, logistics service providers generally carry goods by trucks and vans to the city entrance, namely to UCC. Later, goods can be sorted and consolidated via this city platform and transhipped to light commercial vehicles such as minivans, electric vans, and cargo bikes to deliver in the city centre for the last mile deliveries (Simoni et al., 2018). This distribution scheme aims at achieving a high level of load utilisation by promoting cooperative freight transport systems (Browne et al., 2007). From this perspective, collaboration among logistics service providers can facilitate reaching economies of scale by reducing both operation and transportation costs. Also, the transhipment of goods through smaller, lighter, and cleaner commercial vehicles can be helpful to decrease negative externalities such as air pollution, noise, and congestion (Lagorio et al., 2016).

On the other hand, studies about UCCs show that this city platform has limitations for implementing into the competitive environment and can create costs more than benefits for its users. UCC, which is generally situated far from the city centre due to the lack of sufficient space for conducting such a large facility in urban areas, requires travelling a long distance to an inner-urban area with light commercial vehicles featuring limited capacity and low speed (Simoni et al., 2018). Integrating UCC to conventional distribution systems can lead to extra costs result from transhipment goods to the dedicated facility, operating this facility, designing the fleet in charge of environmentally friendly, and ensuring the delivery service to customers (Verlinde et al., 2014). Also, Danielis, Rotaris, \& Marcucci (2010) state that UCC is mostly not financially viable for an extended period because the surviving conditions of giant facilities highly depend on public subsidies or strong political commitment. According to arising these concerns, downscaling the consolidation effort's scope by using micro initiatives is started to get more attention from the perspective of feasibility (Janjevic et al., 2013). 


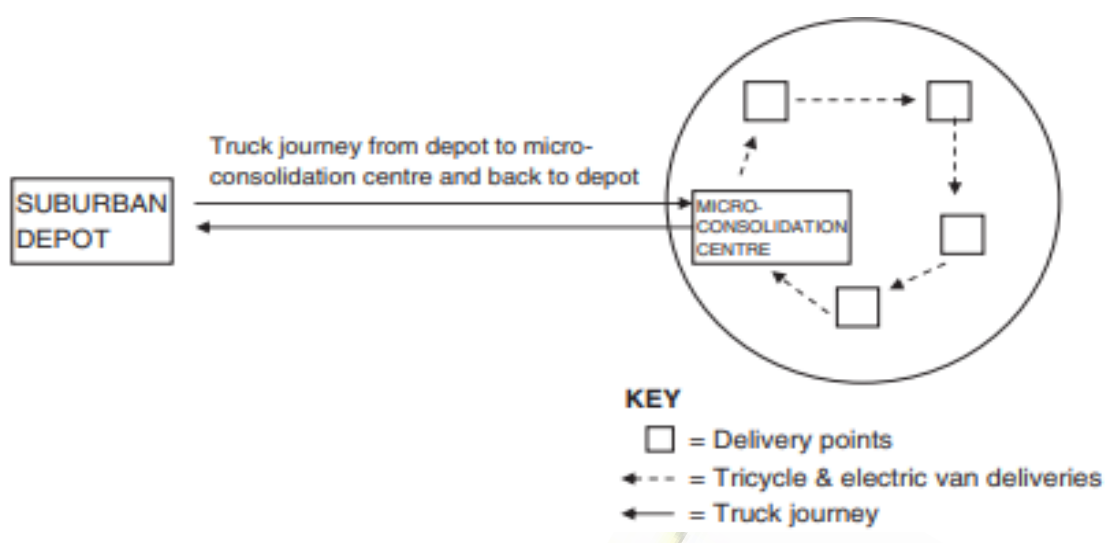

Figure 2. Distribution via MCC

Source: Adopted from Browne, Allen, \& Leonardi (2011)

Micro-consolidation centre (MCC) can be defined as the smaller scale of typical UCCs but situating much closer to the reception point. MCC adopts a similar distribution scheme, focusing on consolidated deliveries in inner-urban areas by light commercial vehicles making rationalised rounds. As shown in Figure 2, the bundling of goods occurs in the suburban depot or urban logistics centre, arranging consolidated transport to MCC to reduce the total vehicle trips in density areas. However, in opposition to UCCs, MCCs have a more limited spatial scope, commonly suitable for the delivery's last leg for parcels in opposition to pallets (Janjevic \& Ndiaye, 2014). Moreover, while MCC can be employed to distribute goods to multilocated reception points, it can also be utilised as the pick-up point, namely as the reception point itself (Browne et al., 2011).

Mobile depots, as the last city distribution platform, consist of a suburban depot in conjunction with a mobile logistics facility used for the consolidated transport of goods to the urban area and includes all the necessary equipment and vehicles for the final stage of delivery (Janjevic \& Ndiaye, 2014). A Mobile depot can be defined as a vehicle consisting of a trailer fitted with a loading dock, warehousing facilities, and office (Arvidsson \& Pazirandeh, 2017). In this distribution scheme, parcels are loaded into the mobile depot at the suburban depot or logistics centre according to their reception points, and then the mobile depot drives to the city centre with all parcels of that day. At this point, this vehicle can be a pick-up point in the central parking location as well as parcels are delivered from this point by electrically supported cycle cargos. Although the mobile depot can be seen relatively recent initiative to be adopted 
among all consolidated-distribution platforms, the ex-ante studies on the case of the

TNT Express initiative in Brussels provide a clue about its pros and cons (Straightsol, 2012; Arvidsson \& Pazirandeh, 2017).

Table 2. The Evaluation of City Distribution Schemes

\begin{tabular}{|c|c|c|c|c|}
\hline & & Benefit & Cost \\
\hline \multirow{3}{*}{ 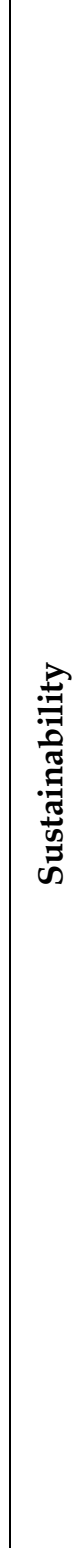 } & \multirow{3}{*}{ 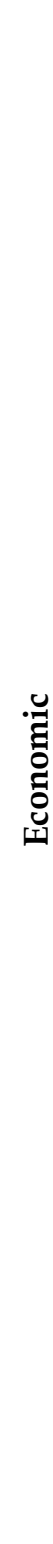 } & ט & $\begin{array}{l}\text { - Procurement-led solutions } \\
\text { - Fewer vehicle trips/ } \mathrm{km} \text { in the city } \\
\text { - Taking advantage of economies of scale } \\
\text { - Promoting collaboration among logistics } \\
\text { - service providers } \\
\text { - Storage opportunity for a significant number } \\
\text { of goods ranges } \\
\text { - Serving to the wide urban area } \\
\text { - Opportunity for providing value-added } \\
\text { - } \text { services } \\
\text { chain operations }\end{array}$ & $\begin{array}{l}\text { - High set up and operating costs } \\
\text { - Difficulty in handling a wide range of } \\
\text { goods } \\
\text { - Travelling the long distance to } \\
\text { customer density areas with limited } \\
\text { capacity and low-speed vehicles } \\
\text { - Highly depend on public subsidies or } \\
\text { strong political commitment to be } \\
\text { viable } \\
\text { - Possible protests from companies that } \\
\text { are good at conventional distribution } \\
\text { - Difficult to use as a reception point due } \\
\text { to the distance to the city. }\end{array}$ \\
\hline & & $\sum_{\Sigma}^{U}$ & $\begin{array}{l}\text { - Solutions related to upstream supply chain } \\
\text { - Reducing the total vehicle trips performed in } \\
\text { the city centre } \\
\text { - Usage in both delivering goods and being a } \\
\text { reception point } \\
\text { - Providing additional transhipment point for } \\
\text { city distribution } \\
\text { - Strategic position between population density } \\
\text { - } \text { and shippers } \\
\text { - } \text { loads } \\
\text { Ensuring elasticity to customer delivery } \\
\text { - High mobility in the defined city area } \\
\text { - Supporting same-day deliveries }\end{array}$ & $\begin{array}{l}\text { - More delivery activity per day } \\
\text { - İnsufficient storage volume } \\
\text { - Difficulty in finding out a suitable } \\
\text { location in the central area } \\
\text { - High land acquisition cost in the city } \\
\text { centre }\end{array}$ \\
\hline & & 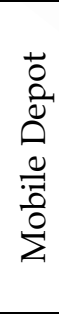 & $\begin{array}{l}\text { - High mobility in the inner-urban area } \\
\text { - Usage in both delivering goods and being a } \\
\text { reception point } \\
\text { - Financially viable for an extended period } \\
\text { - Economically competitive for logistic service } \\
\text { - } \text { Eroviders } \\
\text { - Ensuring same-day deliveries }\end{array}$ & $\begin{array}{l}\text { - The requirement of high capital } \\
\text { investment } \\
\text { - Additional handling cost and time } \\
\text { occupancy } \\
\text { - Lack of volume of the tricycles } \\
\text { - High depreciation rate }\end{array}$ \\
\hline
\end{tabular}




\begin{tabular}{|c|c|c|c|}
\hline \multirow{3}{*}{$\begin{array}{l}\bar{\pi} \\
\mathscr{J} \\
\omega\end{array}$} & 己. & $\begin{array}{l}\text { - } \text { Enhancing delivery reliability } \\
\text { - Reducing the impact on total traffic } \\
\text { - } \text { A safe environment for receivers due to a } \\
\text { reduction in heavy commercial vehicles on } \\
\text { the road } \\
\text { - İmproving customer satisfaction } \\
\text { - Providing more flexible deliveries such as } \\
\text { - } \text { integration with night logistics } \\
\text { - Taking advantage on behalf of society as } \\
\text { behaving socially concerned }\end{array}$ & $\begin{array}{l}\text { - Increasing traffic level near UCC } \\
\text { - Increase in the day-time road space } \\
\text { - Reduction in direct contact with } \\
\text { customers } \\
\text { - Doubts about adopting distribution } \\
\text { scheme by whole actors in society }\end{array}$ \\
\hline & $\stackrel{u}{\Sigma}$ & $\begin{array}{l}\text { - Reducing the freight traffic volume on the } \\
\text { - Arban roads } \\
\text { - } \text { by on a walk } \\
\text { - Flexible delivery into constrained areas by } \\
\text { soft transportation modes } \\
\text { - Close communication with citizens } \\
\text { - Arranging more accurate deliveries from } \\
\text { - Improcts of volume, time and place } \\
\text { - Better management in returns service }\end{array}$ & $\begin{array}{l}\text { - Increasing traffic level near MCC } \\
\text { - Negative attitudes have arisen to the } \\
\text { facility located in the city centre } \\
\text { - Increase in the likelihood of cargo theft }\end{array}$ \\
\hline & $\begin{array}{l}\overrightarrow{0} \\
\frac{0}{0} \\
0 \\
\frac{0}{00} \\
\sum_{0}^{0}\end{array}$ & $\begin{array}{l}\text { - Providing reliable and fast deliveries to } \\
\text { citizens } \\
\text { - Reachable reception point as walking } \\
\text { distance } \\
\text { - High level of customer experience }\end{array}$ & $\begin{array}{l}\text { - Difficulties in achieving coordination } \\
\text { among the city actors } \\
\text { - Problems about fair sharing of risks } \\
\text { and rewards } \\
\text { - Resistances to change by whole actors } \\
\text { in society }\end{array}$ \\
\hline \multirow{3}{*}{ 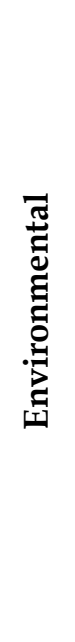 } & U & $\begin{array}{l}\text { - Transporting by light commercial vehicles } \\
\text { such as minivans, electric vans } \\
\text { - Reducing CO2 emissions per parcel }\end{array}$ & - Visual disturbance in its situated area \\
\hline & $\dot{U}$ & $\begin{array}{l}\text { - Usage of clean vehicles or soft transportation } \\
\text { modes such as cargo-bikes and electrically } \\
\text { assisted trolleys } \\
\text { - Conducting emission-free operation }\end{array}$ & $\begin{array}{l}\text { - Probability of noise and visual } \\
\text { disturbance in the near area }\end{array}$ \\
\hline & 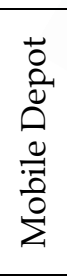 & $\begin{array}{l}\text { - Integration of environmentally friendly } \\
\text { vehicles such as diesel vans and electric } \\
\text { tricycles } \\
\text { - Reducing the impact on congestion, noise, } \\
\text { and visual intrusion } \\
\text { - Conducting emission-free operation }\end{array}$ & - Space occupancy in the city centre \\
\hline
\end{tabular}

Source: Created by the author.

Table 2 points out the evaluation of city distribution schemes based on the costs and benefits of consolidation-distribution city platforms on sustainability dimensions, namely economic, social, and environmental. It is seen that all of the city platforms are compliable with environmental expectations. In contrast, the highlighted topics in 
economic and social aspects should be detailed assessed by city stakeholders in terms of a holistic manner to enhance the liveability of cities.

As a result of the detailed literature review, the importance of consolidationdistribution platforms in the city logistics framework has been revealed. Contrary to the lack of a comparable analysis for city distribution schemes in the current studies, this study provides a detailed feasibility frame of city distribution platforms in the scope of sustainability.

\section{METHODOLOGY}

This study's main objective is to employ an ex-ante evaluation of city distribution alternatives on the typology of consolidation-distribution schemes based on ensuring mutual benefits to each city actors from the city logistics framework. The ex-ante evaluation refers to conducting a prior study to evaluate the pros and cons of a strategy, a project, or an establishment to reach accurate insight regarding feasibility in the implementation stage (Spanache \& Havas, 2019). In this study, based on cost and benefit analysis of consolidation-distribution schemes regarding sustainability dimensions, setting the ex-ante evaluation framework of distribution alternatives is adopted. From this perspective, evaluation according to the cost and benefits in economic, social, and environmental aspects for each alternative can point out a more realistic view of the total impact on a decision in terms of urban well-being. Concerning supporting decision-making for the ex-ante evaluation of the possible alternatives, this study considers the stakeholders' interests and preferences based on aiming to the more significant commitment from all city actors.

The study sample consists of the stakeholders of city logistics in İzmir, which is the third-largest city in Turkey. Since the study aims to reveal stakeholders' expectations concerning consolidation-distribution alternatives in urban areas, logistics service providers, shippers, receivers, local authorities, and citizens in İzmir city were involved study's framework. In the study conducted by Saaty \& Özdemir (2014), the issue of what the sample size should be in order to have high accuracy rates by obtaining error minimisation and consistent comparison matrices in AHP analysis and similar MCDM based methods were discussed. Accordingly, it was stated that if 
the participants from different backgrounds are included in the study, the number per group should be limited to seven people. There is a strong correlation between a larger sample size in the MCDM studies and the probability of inconsistent analysis results (Pun \& Hui, 2001). The main point for MCDM methods is to determine the decisionmakers who need their opinion on the subject and that these decision-makers are knowledgeable in their field. In parallel with it, data were collected via a structured online questionnaire from 25 people with all groups have the same number of participants.

It was paid attention that the logistics service providers, receivers, and shippers from the participant groups have at least ten years of work experience. Also, the participants representing the local authority were composed of authorised persons in the Izmir Metropolitan Municipality urban planning department. At the beginning of the questionnaire, preliminary information given about the study framework regarding criteria and alternatives was shared with stakeholders due to the reason that the topic can be unfamiliar for some of them. Also, since data collected from city logistics stakeholders were before January 2020, the study did not require ethics committee approval.

This study adopts the Multi Actor Multi-Criteria Analysis (MAMCA) to evaluate different city actors' expectations and a set of city distribution alternatives holistically. MAMCA was developed by Macharis (2000) and applied in various fields, especially in the domain of mobility and logistics related to transport-related decision making (Huang, Lebeau, \& Macharis, 2020). Unlike classical Multiple-criteria decisionmaking (MCDM) methods that adopt a set of standard criteria for each stakeholder for ranking and evaluating, the MAMCA framework aims to highlight deep insights of each stakeholder as defining different criteria tree regarding expectations (Macharis, 2007). MAMCA is a comprehensive analysis method that includes the application of different MCDM methods. Although MCDM analyses such as AHP, Fuzzy AHP, and SMART are used in different parts of the analysis, the approach results in a holistic visualisation of these analyses from the MAMCA framework in terms of compliance with different stakeholder expectations based on alternatives. MAMCA framework is performed using MAMCA Software which is a web tool developed for MAMCA 
projects to facilitate transaction procedure and visualisation while maximising stakeholder involvement (Huang et al., 2020). In this study, all analysis within the framework of MAMCA was carried out using MAMCA Software. The MAMCA framework can be seen in Figure 3.

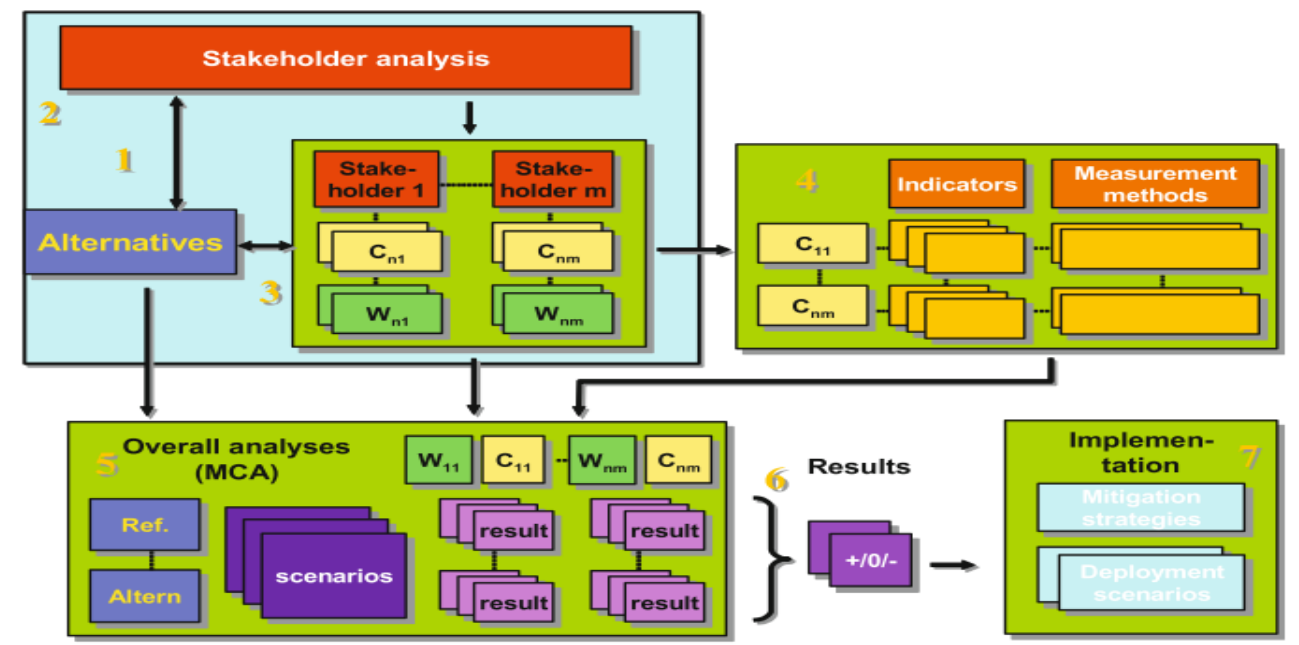

Figure 3. The MAMCA Framework

Source: Adopted from Macharis (2007)

In parallel with Figure 3, the MAMCA framework consists of the following steps:

- 1st Step: Defining alternatives or scenarios to reveal stakeholders' insights into the decision-making process.

- 2nd Step: Identifying all stakeholders involved in related to the conceptual framework of alternatives considered.

- 3rd Step: Determining the objectives of stakeholders as criteria and analysing the importance that they associate with these criteria. In this step, any MCDM analysis such as Analytic Hierarchy Process (AHP) or Fuzzy AHP can be used to determine the weights of criteria comparatively that the stakeholder is attaching to (each of) his or her objectives.

This study adopts Saaty's AHP approach to calculate the weights of the criteria. According to a pair-wise comparison procedure in the AHP approach, a 1-9 scale shows how much more strongly an objective contributes to the main expectation arisen than the objective with which it is being compared. For a comprehensive overview of 
Saaty's AHP approach, refer to Saaty (1987).

- 4th Step: Associating each criterion to a measurable or qualitative indicator to explain the content related to what extent an alternative contributes to each criterion.

- 5th Step: Ranking the different strategic alternatives concerning the decision criteria handled.

In this step, any MCDM analysis can be used to rank alternatives according to each stakeholder's criteria in a holistic manner. As the MAMCA Software can implement ranking according to SMART (Simple Multi-Attribute Rating Technique) approach, this study adopts the SMART evaluation method by asking stakeholders to rank alternatives based on their criteria in the range of 1-10 scale. For a comprehensive overview of the SMART approach, refer to the study of Edwards (1977).

- 6th Step: Obtaining an overall classification of the proposed alternatives with MAMCA analysis as highlighting the performance of the alternatives on the stakeholders' criteria.

- 7 th Step: It is resulting in implementation plans for optimal alternative adopted mostly by stakeholders.

The study's roadmap in line with the implementation steps of the MAMCA framework is presented in Figure 4. 


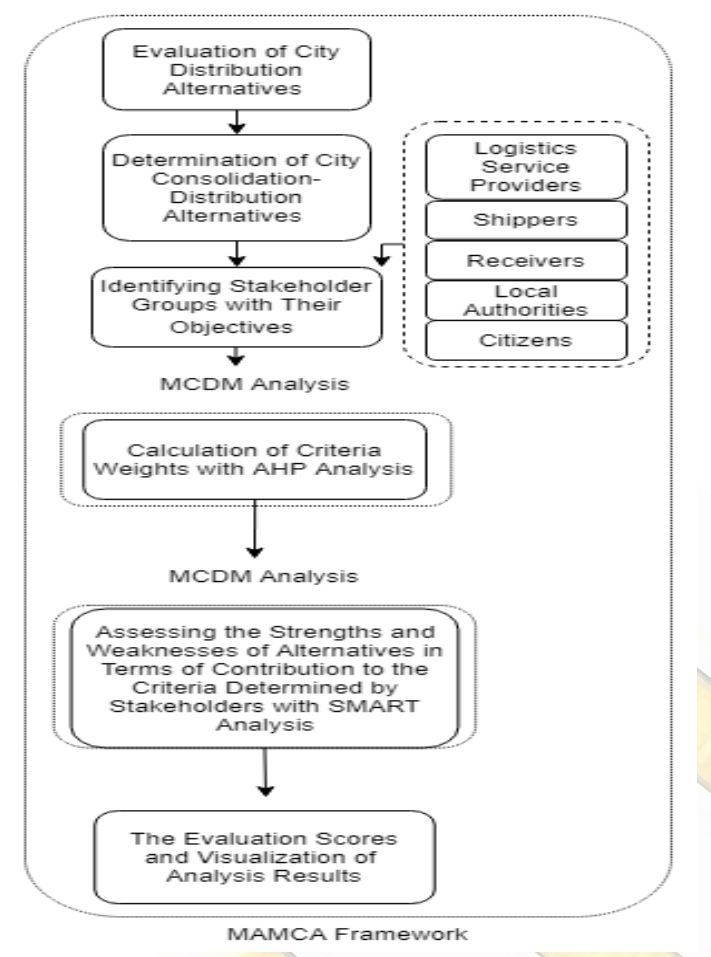

Figure 4. The Study's Roadmap

Source: Created by the author

\section{ANALYSIS AND RESULTS}

\subsection{Step 1: Defining Alternatives}

Based on an in-depth examination of city logistics literature on sections 2.1 and 2.2., city consolidation-distribution alternatives were defined. Also, in the literature review section, these alternatives' costs and benefits were evaluated to provide a more accurate decision process for all stakeholders in detail. From these perspectives, alternatives, aiming to implement in the scope of İzmir city, include suggestions to improve liveability from the city logistics framework. As the first step of the MAMCA framework, proposed alternatives to be employed in İzmir city can be shown as follows:

- Alternative 1: UCC distribution scheme

- Alternative 2: MCC distribution scheme

- Alternative 3: Mobile Depot distribution scheme 


\subsection{Step 2 and Step 3: Identifying Stakeholders and The Criteria Weights}

As the second step of MAMCA, studies related to urban freight distribution, mobility, and city logistics were examined regarding stakeholders' involvement. Aljohani \& Thompson (2019) determine six categories of stakeholders: logistics services providers, logistics property providers, receivers, shippers, local authorities, and citizens to evaluate sustainable delivery fleet for freight consolidation policies. The study by Huang et al. (2020), concerning the evaluation of the last-mile solutions, identifies city stakeholders as citizens, local authorities, logistics service providers receivers, and shippers. Generally, these stakeholders are involved in the concept of similar logistics topics (Verlinde et al., 2014; Lebeau, Macharis, Van Mierlo, \& Janjevic, 2018). In parallel with these, this study identifies stakeholders as the logistics services providers, receivers, shippers, local authorities, and citizens to determine the best alternative of the city consolidation-distribution schemes.

Based on a detailed review of the literature, an initial list of each stakeholder group's main objectives was determined. Mainly, each group's objectives were designed according to relevant perspectives regarding the city logistics concept. The objectives were then sent to associated people in stakeholder groups to ask for a comment on proposed objectives and additional objectives for the stakeholder group they in. Feedback with additional objectives was taken into account to generate the final list of objectives and transform them into criteria.

Later, a structured online questionnaire form was sent to each group member to assess the criteria' weight in terms of each group's objectives based on the pair-wise comparison expressed on a 1-9 ratio scale in the AHP method. The questionnaires filled out individually were combined via geometric mean (see in Yadav \& Jayswal, 2013) in condition with the consistency ratio (CR) is below from 0.10 and obtained standard eigenvectors per criterion representing the group's decision. After that, all AHP procedure was conducted by MAMCA Software. The final list of objectives, criteria, and each stakeholder group's weight obtained by the AHP method is shown in Table 3. 
Table 3. Stakeholder Groups with Their Objectives and Weighted Criteria

\begin{tabular}{|c|c|c|c|}
\hline Stakeholder & Objective & Criterion & Weight \\
\hline \multirow{5}{*}{$\begin{array}{l}\text { Logistics } \\
\text { Services } \\
\text { Providers }\end{array}$} & Receiver and shipper satisfaction & Level of service & 0.227 \\
\hline & Low cost of collecting and delivering products & Transportation cost & 0.316 \\
\hline & A positive return on investment & Viability of investment & 0.278 \\
\hline & Positive impact on social and environmental & Impact on society & 0.179 \\
\hline & concerns & & \\
\hline \multirow{3}{*}{ Receivers } & Deliveries on-time and problem-free & Level of service & 0.367 \\
\hline & Low cost of receiving parcels & Parcel receiving cost & 0.408 \\
\hline & Positive attitude towards environmental impact & Green concerns & 0.225 \\
\hline \multirow{3}{*}{ Shippers } & Effective and on-time delivery to receivers & Level of service & 0.427 \\
\hline & Low cost of delivering products to receivers & Delivery cost & 0.369 \\
\hline & Positive attitude towards environmental impact & Green concerns & 0.204 \\
\hline \multirow{3}{*}{$\begin{array}{l}\text { Local } \\
\text { Authorities }\end{array}$} & $\begin{array}{l}\text { The liveable city for citizens with limited } \\
\text { externalities (noise, emission and congestion) }\end{array}$ & Liveable city & 0.479 \\
\hline & The utilisation of existing infrastructure & Network utilisation & 0.313 \\
\hline & Attractive environment for companies & Business climate & 0.208 \\
\hline \multirow{3}{*}{ Citizens } & $\begin{array}{l}\text { An attractive environment with limited } \\
\text { externalities (noise, emission and congestion) }\end{array}$ & Quality of life & 0.515 \\
\hline & Fewer traffic accidents and high road safety & Traffic safety & 0.318 \\
\hline & Constant availability of products in stores & Product availability & 0.167 \\
\hline
\end{tabular}

Source: Created by the author

The logistics service providers, which refer to carriers, express services, or the forwarders, offer the door-to-door transport service according to demand arisen from the shippers and the receivers. As shown in table 3, transportation cost represents the most crucial criterion for logistics service providers with a $32 \%$ weight. The total cost paid to deliver in the inner-urban area can indicate measurement regarding conducting operations efficiently. The viability of the investment and high service level shows the second and third most crucial criterion with respective weights of $28 \%$ and $23 \%$. Notably, while high return on investment is an essential measure of competitiveness, this will be sustainable with the service quality provided at a level that will create satisfaction for receivers and shippers. The least essential criterion with 
$18 \%$ weight compared to other criteria is the impact on society. Although this criterion indicates the company's responsibilities over society in all operations carried out, it is essential after its economic goals.

Receivers as a stakeholder group can be mainly categorised as retailers, wholesalers, and residents. As presented in table 3, the parcel receiving cost represents the most critical criterion with $41 \%$ weight. This criterion, which stands out with the same degree of importance in logistics service providers, expresses receivers' expectation towards decreasing in receiving cost as a reflection of transportation costs. The level of service and green concerns constitutes the second and third most highlighted criterion with a respective weight of $37 \%$ and $23 \%$. Receivers who demand a high level of service, especially a timely and undamaged delivery, expect a positive environment based on environmental awareness.

Shippers can be defined as manufacturers, wholesalers, or retailers and send the goods to the receivers from the depots they operate. As long as shippers keep the receivers' satisfaction level high, they can be retained in the market. In line with this fact, the service level indicates the most prominent criterion with $43 \%$ weight. Besides, reducing delivery costs is the second important criterion with $37 \%$, regardless of whether the operations are carried out on their own or through the logistics service provider. Lastly, to create a company image with a high sense of responsibility towards the society, green concerns show the third most crucial criterion with $20 \%$ weight.

Citizens elect the local authorities to design and govern the urban areas' framework concerning creating a better environment for all citizens. As shown in table 3 , a liveable city constitutes the most crucial criterion with $48 \%$ as local authorities' main effort consists of reducing negative externalities in terms of noise, emission, and congestion for all citizens. On the other hand, to optimal use of existing infrastructure, network utilisation represents the second most highlighted criterion with $31 \%$. As a last, the business climate criterion, which expresses the design of an enabling environment to increase commercial activities, is the third most essential criterion with $21 \%$ weight. 
In general, citizens consist of the end-consumers of the goods entering the city and demand solutions regarding enhancing their quality of lives in the urban area. In parallel with it, the criterion of quality of life indicates the most crucial dimension with $52 \%$, including demands towards reducing negative externalities concerning noise, emission, and congestion in their living area. Because one of the most problematic issues is traffic accidents result from heavy commercial vehicles, traffic safety criterion is the second important topic with $32 \%$. Finally, considering that city residents take on the role of customers to maintain their daily lives, the product availability criteria for continuity in the supply of products in stores constitutes the third crucial criterion with $17 \%$ weight.

\subsection{Step 4 and Step 5: Indicators and The Assessment of Alternatives}

Concerning Table 3, most of the criteria, such as the impact on society, level of service, and quality of life, cannot be expressed numerically. Moreover, quantitative data from the local freight industry was difficult to obtain with exact numbers due to information privacy reasons. Thanks to the MAMCA framework's strengths, conducting the multi-criteria analysis of the alternatives can also be possible regarding the qualitative indicators to associate each criterion (Roukouni, Macharis, Basbas, Stephanis, \& Mintsis, 2018). In parallel with it, the qualitative indicators and measurement units were obtained through an in-depth literature review and negotiations with experts in the freight industry to draw insights in the conclusion stage to what extent an alternative contributes to a criterion.

In assessing the different alternatives for each of the criteria, the MAMCA Software was utilised to conduct the SMART analysis. Accordingly, participants in each stakeholder group were asked for ranking alternatives based on each of the group's criteria in the range of 1-10 scale (1 is the most negative score, 10 is the most positive score). After that, the arithmetic mean of the participants in the same stakeholder groups' answers was taken to form the group score, and it was processed in the MAMCA Software. 


\subsection{Step 6 and Step 7: Results and Ranking of Alternatives}

Comparing the alternatives pair-wise to each stakeholder group's weighted decision tree based on the MAMCA framework reveals the study's overall results. The evaluation weights of proposed city consolidation-distribution alternatives can be seen in Table 4. The visualisation of the multi-actor view related to the rank of alternatives by MAMCA framework can be examined in Figure 5.

Table 4. The Evaluation Scores within the MAMCA Framework

\begin{tabular}{|c|c|c|c|}
\hline \multirow{2}{*}{ Stakeholder } & Alternative 1: & Alternative 2: & Alternative 3: \\
\cline { 2 - 4 } & UCC Distribution & MCC Distribution & Mobile Depot Distribution \\
& Scheme & Scheme & Scheme \\
\hline $\begin{array}{c}\text { Logistics } \\
\text { Services } \\
\text { Providers }\end{array}$ & 0.354 & 0.564 & 0.482 \\
\hline Receivers & 0.259 & 0.437 & 0.451 \\
\hline Shippers & 0.391 & 0.363 & 0.278 \\
\hline Local & 0.321 & 0.490 & 0.390 \\
\hline Authorities & & & \\
\hline Citizens & 0.402 & 0.551 & \\
\hline
\end{tabular}

Source: Created by the author 


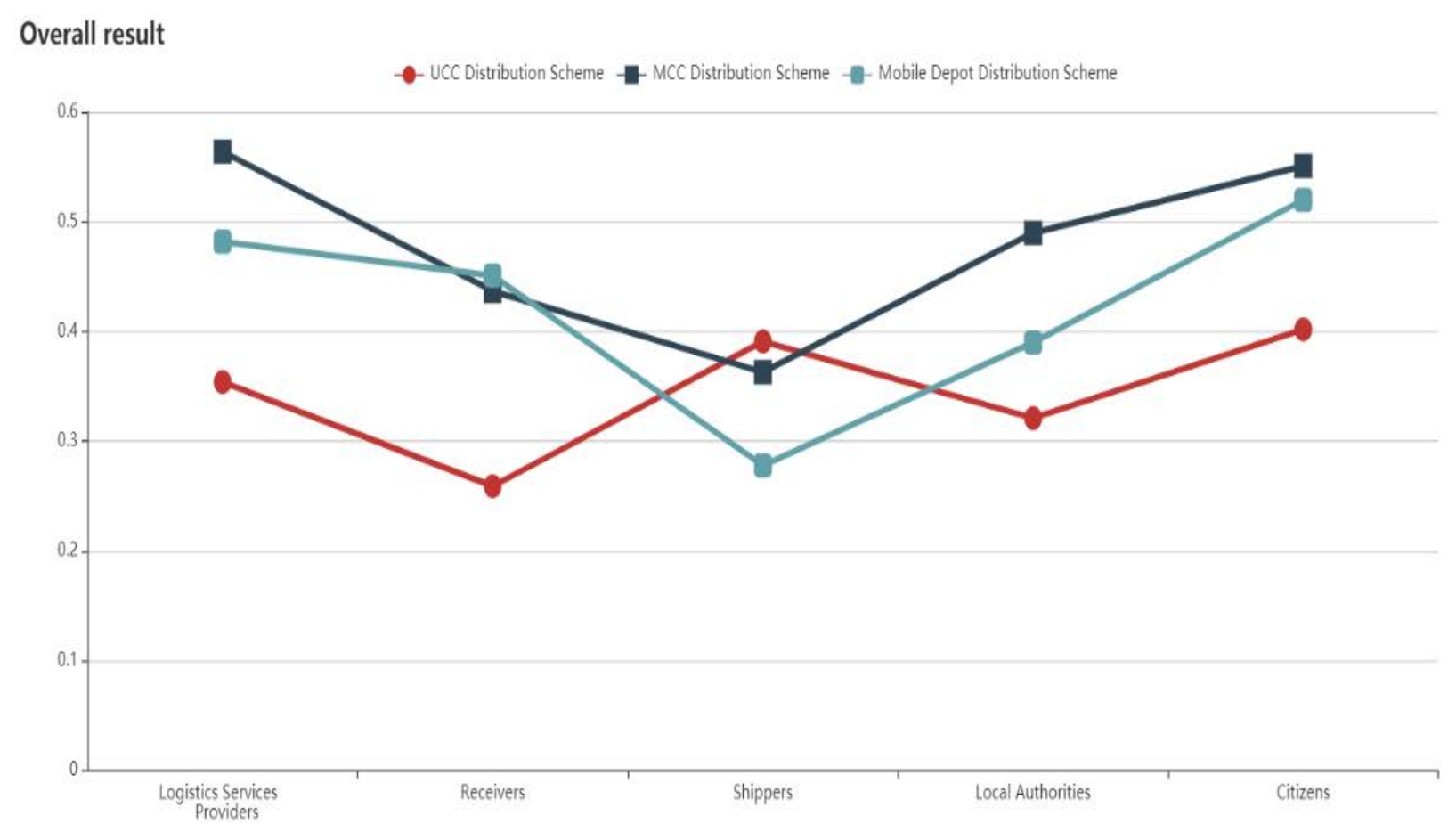

Figure 5. Visualisation of The MAMCA Analysis Results Source: Created by the author via MAMCA Software

In compliance with Table 4 and Figure 5, the overall evaluation of alternatives based on stakeholders' expectations can be explained. As a first alternative, integrating the UCC distribution scheme to the city obtained the lowest evaluation scores from almost all stakeholders groups except the shippers' group. Shippers considered UCC, which is generally located outside of the city, enabling the products to reach out-ofcity receivers quickly and effectively, as the most suitable distribution scheme for their expectations. Shippers regarded this distribution scheme as the most viable alternative in terms of the city consolidation centre's procurement-led solutions and value-added services, the possibility of reducing delivery costs by providing an economy based on scale economy, and ensuring urban deliveries with environmentally-friendly vehicles.

As UCC offers a structure that radically changes the existing conventional distribution network, the network structure of existing facilities established by logistics service providers for urban distribution can become inactive. Besides, the risk towards the long-term financial viability of UCC jeopardises logistics service providers' profitability. UCC was evaluated as disadvantageous for receivers in terms of inconvenient location for the pick-up of products and lack of personalised services. UCC distribution scheme can be perceived as the possible intervention that may affect 
competitiveness in the city, especially in terms of the business climate, by local authorities. Also, for citizens, with the integration of UCC into the city, the number of commercial vehicles on the roads may still be high, and it causes problems in terms of traffic congestion. Given all these approaches, it is not surprising that the city consolidation centre scored the lowest except for shippers.

The mobile depots increase the customer experience in terms of their receiveroriented facilities, such as being located in the city centre as a reception point, providing fast and environmentally friendly delivery, and providing returns efficiently. In this regard, integrating a mobile depot scheme into city distribution achieved the highest evaluation score for receivers. Mobile warehouses, which were evaluated as the second most crucial alternative for almost the rest of the stakeholders' groups, also considered from attributes such as the limited capacity of the cargo bikes, occupation of space in the city centre, and high depreciation rates of vehicles.

The MCC distribution scheme has obtained a relatively high evaluation score by all the stakeholder groups. MCC was seen as the best alternative for logistics service providers in terms of locating in dense areas to form a strategic last-mile delivery network, providing smooth deliveries in inner-urban areas, and implementing valueadded services regarding unique customer demands. Also, reducing the impact on the freight traffic volume, creating an intimate communication environment with citizens, delivering by soft transportation modes, and arranging more accurate deliveries in terms of volume, time, and place can be seen as important points to the other stakeholders' groups.

\section{CONCLUSION AND DISCUSSIONS}

This study examines an ex-ante evaluation of city distribution alternatives on the typology of consolidation-distribution schemes from multi-actor perspectives based on ensuring win-win solutions to each city actors in the city logistics framework. In particular, the intention is to shift the emphasis toward more practical aspects of the city logistics, such as the Urban Consolidation Centers (UCCs), the Micro Consolidation Centers (MCCs), or Mobile Depots. These city platforms promote the 
idea of consolidating in cooperation towards achieving the value-creating process and sustainability through synergies.

According to the study's framework, the main research questions can be handled, respectively. Firstly, the costs and benefits of different city consolidationdistribution alternatives from the sustainability aspects regarding economic, social, and environmental were evaluated. It was a pioneer study to assess all three city platforms holistically: UCC, MCC, and mobile depot. Remarkably, the cost and benefit analysis is a supportive tool to evaluate these concepts from an ex-ante perspective concerning the before implementation or strategic decision. From this point, considering all city actors' aims with a more in-depth examination of alternatives with their pros and cons can be indicated as crucial ex-ante to cope with strategic city decisions and compensate if necessary (Macharis, 2007).

This study adopts Multi Actor Multi-Criteria Analysis (MAMCA) framework as an extension of the widely used multi-criteria decision-making techniques to evaluate different city actors' objectives and a set of city distribution alternatives in a comprehensive manner. As city logistics is a multi-actor complex phenomenon, regarding the two other research questions, city logistics literature indicated five main stakeholders: logistics services providers, receivers, shippers, local authorities, and citizens with different interests and objectives. Later, based on a detailed review of the literature and feedback from stakeholders' groups in İzmir city, the final list of objectives and criteria was obtained. After weighted criteria by the AHP method for each stakeholder, proposed alternatives were evaluated based on each criterion by the SMART method. As a result of this study, the MAMCA framework resulted in with overall evaluation of criteria and alternatives from the multi-actor approach to understanding which city distribution scheme is desired by which actors.

The fact that city consolidation-distribution platforms are generally examined separately in studies shows a lack of comprehensive manner to evaluate these three concepts comparatively (Lagorio et al., 2016). In addition to it, these city platforms require ex-ante evaluation to figure out being compliant with city logistics dynamics in the aspect of feasibility. On the other hand, a holistic manner based on stakeholder 
involvement in city logistics decisions must figure out the solutions' feasibility. Studies on city logistics mostly underestimate this perspective (Lagorio et al., 2016; Macharis \& Baudry, 2018). Contrary to the shortcomings of the existing studies, this study employs a holistic approach to evaluate city consolidation-distribution platforms' pros and cons and consider city actors' expectations regarding the city logistics framework.

In the MAMCA framework, the most important alternative to implementing in the city distribution network was determined as MCC. Providing unique solutions to all stakeholders regarding their expectations can be influential in the decision of implementing this consolidation-distribution scheme. These findings are in parallel with the results of the studies of Janjevic \& Ndiaye (2014) and Lagorio et al. (2016). Moreover, this is the ex-ante study for İzmir, Turkey's third-largest city, to present a solution for facilitating the city's liveability in terms of city logistics. In conclusion, to support future decisions that will be taken for strategic planning purposes, which can be influenced by different parameters, existing improvements, and trade-offs, this study's assessment method can be adopted by stakeholders mainly involved in the city logistics framework.

\section{SUGGESTIONS}

City logistics is a multi-actor complex system that ensures carrying out the delivery of goods in urban areas as the last link of the supply chain. The idea based on future cities emphasises that all city decisions should be taken with a modern, inclusive, and participatory approach. However, studies in Turkey related to the city logistics domain suffer a lack of examination through city stakeholders' expectations. In future studies, it is recommended to focus on multi-actor approaches in order to achieve more sustainable and inclusive urban logistics solutions. Since the MAMCA framework can evaluate the expectations of decision-makers and the proposed decisions with a holistic approach, its application rate in studies worldwide is gradually increasing. In this respect, it is recommended to examine studies in different application areas such as inclusive urban policies, sustainable logistics scenarios, and innovative delivery alternatives with this analysis method. 
Conducting more detailed studies on the applicability of urban consolidation platforms is essential for the future of urban logistics. In particular, cost/benefit analysis for urban distribution schemes based on real sector information will enrich the field. It is also recommended to carry out sector-specific or market-type studies to make operational, tactical, and strategic decisions regarding planning urban load flow. In future studies, this study, in which city consolidation centres are evaluated, can be transformed into integrated scenarios with different delivery models, and more comprehensive solutions can be achieved. Since the logistics sector is quite dynamic, it is essential to follow new technologies and developments. Practitioners in the sector can gain insight into which distribution scheme can be integrated into future logistics applications in line with this study. Nowadays, where the cooperation strategy is increasing in order to compete in the sector, consolidation-distribution alternatives that offer sustainable solutions are expected to contribute to the practitioners. 


\section{REFERENCES}

Aljohani, K., \& Thompson, R. G. (2018). Optimising the Establishment of a Central City Transshipment Facility to Ameliorate Last-Mile Delivery: a Case Study in Melbourne CBD. City Logistics 3: Towards Sustainable and Liveable Cities, 23-46.

Aljohani, K., \& Thompson, R. G. (2019). A stakeholder-based evaluation of the most suitable and sustainable delivery fleet for freight consolidation policies in the inner-city area. Sustainability, 11(1), 124.

Allen, J., Browne, M., Woodburn, A. \& Leonardi, J. (2014), A review of urban consolidation centres in the supply chain based on a case study approach, Supply Chain Forum, 15(4), 100-112.

Arvidsson, N., \& Pazirandeh, A. (2017). An ex ante evaluation of mobile depots in cities: A sustainability perspective. International Journal of Sustainable Transportation, 11(8), 623-632.

Awasthi, A., Chauhan, S. S. \& Goyal, S. K. (2011), A multi-criteria decision making approach for location planning for urban distribution centers under uncertainty, Mathematical and Computer Modelling, Vol. 53(1/2), 98-109.

Bektas, T., Crainic, T. G., \& Van Woensel, T. (2015). From managing urban freight to smart city logistics networks. Retrieved from https://www.cirrelt.ca/DocumentsTravail/CIRRELT-2015-17.pdf. (Last accessed: 20 August 2020)

Benjelloun, A., \& Crainic, T. G. (2008). Trends, challenges, and perspectives in city logistics. Transportation and land use interaction, proceedings TRANSLU, 8, 269-284.

Björklund, M., Abrahamsson, M., \& Johansson, H. (2017). Critical factors for viable business models for urban consolidation centres, Research in Transportation Economics, 64, 36-47.

Björklund, M., \& Johansson, H. (2018). Urban consolidation centre - a literature review, categorisation, and a future research agenda, International Journal of Physical Distribution \& Logistics Management, $48(8), 745-764$.

Browne, M., Woodburn, A. G., \& Allen, J. (2007). Evaluating the potential for urban consolidation centres. European Transport/Trasporti Europei, 35, 46-63.

Browne, M., Allen, J., \& Leonardi, J. (2011). Evaluating the use of an urban consolidation centre and electric vehicles in central London. IATSS research, 35(1), 1-6.

Crainic, T. G., Ricciardi, N., \& Storchi, G. (2004). Advanced freight transportation systems for congested urban areas. Transportation Research Part C: Emerging Technologies, 12(2), 119-137.

Dablanc, L. (2007). Goods transport in large European cities: difficult to organise, difficult to modernise, Transportation Research Part A: Policy and Practice, 41(3), 280-285. 
Daggers, T. (2013). City Logistics with electric vehicles. IBC-International Bicycle Consultancy for ELMOS Electric mobility in smaller cities.

Danielis, R., Rotaris, L., \& Marcucci, E. (2010). Urban freight policies and distribution channels. European Transport \TrasportiEuropei, 46, 114-146.

DESA, U. (2019). United Nations, Department of Economic and Social Affairs, Population Division. World Population Prospects 2019: Highlights.

Ducret, R., \& Delaître, L. (2013). Parcel delivery and urban logistics changes in urban courier, express and parcel services: The French case. Paper presented at the 13th World Conference on Transport Research, July 15-18, Rio de Janeiro, Brazil.

Edwards, W. (1977). How to use multiattribute utility measurement for social decision- making. IEEE Trans. Syst. Man Cybern. 7(5), 326-340.

Faure, L., Burlat, P., \& Marquès, G. (2016). Evaluate the viability of Urban Consolidation Centre with regards to urban morphology. Transportation Research Procedia, 12, 348-356.

Filippi, F., Nuzzolo, A., Comi, A., \& Delle Site, P. (2010). Ex-ante assessment of urban freight transport policies. Procedia-Social and Behavioral Sciences, 2(3), 6332-6342.

Gonzalez-Feliu, J., Salanova Grau, J. M., \& Beziat, A. (2014). A location-based accessibility analysis to estimate the suitability of urban consolidation facilities. International Journal of Urban Sciences, 18(2), 166-185.

He, Z. (2020). The challenges in sustainability of urban freight network design and distribution innovations: a systematic literature review, International Journal of Physical Distribution \& Logistics Management, 50(6), 601-640.

Huang, H., Lebeau, P., \& Macharis, C. (2020). The Multi-Actor Multi-Criteria Analysis (MAMCA): New Software and New Visualizations. In International Conference on Decision Support System Technology, Springer, Cham, 43-56.

Janjevic, M., Kaminsky, P., \& Ndiaye, A. B. (2013). Downscaling the consolidation of goods-state of the art and transferability of micro-consolidation initiatives. European Transport $\backslash$ Trasporti Europei, 54, 14.

Janjevic, M., \& Ndiaye, A. B. (2014). Development and application of a transferability framework for micro-consolidation schemes in urban freight transport. Procedia-Social and Behavioral Sciences, 125, 284-296.

Lagorio, A., Pinto, R., \& Golini, R. (2016). Research in urban logistics: a systematic literature review, International Journal of Physical Distribution \& Logistics Management, 46(10),908-931.

Lebeau, P., Macharis, C., Van Mierlo, J., \& Janjevic, M. (2018). Improving policy support in city logistics: 
The contributions of a multi-actor multi-criteria analysis. Case Studies on Transport Policy, 6(4), 554563.

Macharis C. (2000). Strategische modellering voor intermodale terminals. Socio economische evaluatie van de locatie van binnenvaart/weg terminals in Vlaanderen, Ph.D. thesis, Vrije Universiteit Brussel, Brussels.

Macharis, C., \& Baudry, G. (2018). The Multi Actor Multi Criteria Analysis framework. In DecisionMaking for Sustainable Transport and Mobility. Edward Elgar Publishing.

Macharis, C., (2007). Multi-criteria Analysis as a tool to include stakeholders in project evaluation: The MAMCA method. In: Haezendonck, E. (Ed.), Transport Project Evaluation. Extending the Social CostBenefit Approach. Edward Elgar, Cheltenham, 115-131.

Malindretos, G., Mavrommati, S., \& Bakogianni, M. A. (2018). City logistics models in the framework of smart cities: urban freight consolidation centers. In 4th international conference of supply chain, 14, 15. Pun, K.F., \& Hui, I.K. (2001). An analytical hierarchy process assessment of the ISO 14001 environmental management system. Integrated Manufacturing Systems, 12(5), 333-345.

Roukouni, A., Macharis, C., Basbas, S., Stephanis, B., \& Mintsis, G. (2018). Financing urban transportation infrastructure in a multi-actors environment: the role of value capture. European Transport Research Review, 10(1), 14.

Saaty, R.W. (1987). The Analytic Hierarchy Process-What It Is and How It Is Used, Mathematical Modelling, 9(3-5), 161-176.

Saaty, T. L., \& Özdemir, M. S. (2014). How many judges should there be in a group? Annals of Data Science, 1(3-4), 359-368.

Savelsbergh, M., \& Van Woensel, T. (2016). 50th anniversary invited article-city logistics: Challenges and opportunities. Transportation Science, 50(2), 579-590.

Simoni, M. D., Bujanovic, P., Boyles, S. D., \& Kutanoglu, E. (2018). Urban consolidation solutions for parcel delivery considering location, fleet and route choice. Case Studies on Transport Policy, 6(1), 112124.

Spanache, I., \& Havas, A. (2019). A Practical Guide on Ex Ante Evaluation for Research Infrastructures. Centre for Social Innovation, Wien. ISBN 9783200064058.

Staricco, L., \& Brovarone, E. V. (2016). The spatial dimension of cycle logistics. TeMA-Journal of Land Use, Mobility and Environment, 9(2), 173-190.

Straightsol. (2012). Project demonstrations. Demonstration B: TNT express in brussels - City logistics mobile depot, Retrieved from www.straightsol.eu/demonstration_B.htm. (Last accessed: 12 August 2020) 
Taniguchi, E. (2001). City logistics. Infrastructure Planning Review, 18, 1-16.

Taniguchi, E., Thompson, R. G., \& Yamada, T. (2016). New opportunities and challenges for city logistics. Transportation research procedia, 12(12), 1.

Van Duin, J. H. R., Van Dam, T., Wiegmans, B., \& Tavasszy, L. A. (2016). Understanding Financial Viability of Urban Consolidation Centres. Transportation Research Procedia, 16, 61-80.

Van Rooijen, T., \& Quak, H. (2010). Local impacts of a new urban consolidation centre-the case of Binnenstadservice. nl. Procedia-Social and Behavioral Sciences, 2(3), 5967-5979.

Verlinde, S., Macharis, C., Milan, L., \& Kin, B. (2014). Does a mobile depot make urban deliveries faster, more sustainable and more economically viable: results of a pilot test in Brussels. Transportation Research Procedia, 4, 361-373.

Winkenbach, M., \& Janjevic, M. (2018). Classification of Last-Mile Delivery Models for e-Commerce Distribution: A Global Perspective. City Logistics 1: New Opportunities and Challenges, 209-229.

Yadav, A., \& Jayswal, S. C. (2013). Using geometric mean method of analytical hierarchy process for decision making in functional layout. International Journal of Engineering Research and Technology (IJERT), 2, 5 . 